\title{
香酸カンキツ ‘新姫’の全果実および部位別フラボノイド成分量
}

\author{
市ノ木山浩道 ${ }^{1 *} ・$ 前川哲男 ${ }^{2 a} \cdot$ 後藤正和 ${ }^{3}$ \\ 1 三重県農業研究所紀南果樹研究室 519-5202 南牟婁郡御浜町 \\ 2 三重県農業研究所 515-2316 松阪市嬉野川北町 \\ 3 三重大学大学院生物資源学研究科 514-8507 津市栗真町屋町
}

\author{
Flavonoid Contents of Whole Fruit and Various Tissues of a New Acid Citrus, 'Niihime' \\ Hiromichi Ichinokiyama $^{1 *}$, Tetsuo Maegawa ${ }^{2 a}$ and Masakazu Goto ${ }^{3}$ \\ ${ }^{1}$ Kinan Fruits Tree Laboratory, Mie Prefecture Agricultural Research Institute, Mihama-cho, Minamimuro-gun, Mie 519-5202 \\ ${ }^{2}$ Mie Prefecture Agricultural Research Institute, Matusaka, Mie 515-2316 \\ ${ }^{3}$ Graduate School of Bioresources, Mie University, Tsu, Mie 514-8507
}

\begin{abstract}
A new acid citrus, 'Niihime', Tachibana (Citrus tachibana Tanaka), and Shiikuwasha (C. depressa Hayata) were examined for flavonoid contents of the whole fruit and tissues (flavedo, albedo, vascular tissue, segment membrane, juice vesicle, and seed) at the maturing stage. Seven flavonoid substances, eriocitrin (ECR), narirutin (NRT), hesperidin (HSP), neoponcirin (NPNC), nobiletin (NBL), sinensetin (SNT) and tangeretin (TNG), were determined using HPLC analysis. The three acid citrus contained all flavonoid substances determined in the present study, except for no detection of ECR in Shiikuwasha. 'Niihime' contained more ECR, NRT, NPNC, and SNT than Tachibana and Shiikuwasha. Total contents of the seven flavonoids in the fruit of 'Niihime' were higher than in Tachibana. On the contrary, 'Niihime' contained significantly less NBL (65\%) than Shiikuwasha, while it was similar to Tachibana. 'Niihime' contained significantly less TNG (30 and $24 \%$, respectively) than Tachibana and Shiikuwasha. Flavonoid contents in individual fruit parts of 'Niihime' were as follows: ECR, SNT, NBL, and TNG were highest in the flavedo, NRT and NPNC were highest in vascular tissue, and HSP was highest in vascular tissue and the albedo.
\end{abstract}

Key Words : flavanone, fruit tissues, matured fruit, polymethoxylated flavone

キーワード：フラバノン，果実部位，ポリメトキシフラボン，成熟果実

\section{緒言}

我が国においては，食習慣の乱れによる生活習慣病の増 加が問題となってきている。例光ば，糖尿病は様々な合併 症を引き起こす原因で，年齢とともに有病率が増加する疾 病とされ，食生活などによる予防の重要性が指摘されてい る(間苧谷・田中，2003）。また，高齢化社会の到来により 生活習慣病に対しては, 日常の食生活の中で発病を予防す る動きが活発化してきている（荒井，1999）。

カンキッ類は, フラボノイド, カロチノイド, クマリン, テルペン，リモノイドなどの機能性成分を多く含有してい る(野方, 2005)。フラボノイド類のへスペリジンやナリン ギンには, 癌細胞のアポトーシス誘導作用 (Kanno ら, 2003) や脂質代謝の改善作用（Kim ら，2003），タンゲレチンや）

2011 年 6 月 13 日 受付. 2012 年 2 月 14 日 受理.

* Corresponding author. E-mail: ichinh00@pref.mie.jp

a 現在 : NPO 法人東海地域生物系先端技術研究会
ビレチンには癌細胞の浸潤・転移抑制作用 (Bracke ら, 1994; Minagawa ら, 2001), 血漿 VLDL (very low density lipoprotein) 濃度の低下作用（Manthey, 2000），执よび関節リウマチや 関節破壊症に関与するマトリックスメタロプロテアーゼ産 生阻害作用（Ishiwa ら，2000）のあることが報告されてい る.これら機能性成分をカンキッ生産の活性化につなげよ らといら動きもある（久保ら，1989; 松田ら，1991; 隅田ら， 1999; Tanaka ら，1998; 矢野，1999)。例觉ば，沖縄県特産の シィクワーサー（C. depressa Hayata）には，ポリメトキシ フラボンであるノビレチン含量が高く抗腫瘍形成や抗腫瘍 作用が認められること（Murakami ら，2000; Sato ら，2002） により, 栽培農家の活性化に結びついている（太田, 2004). また，和歌山県特産の ‘じゃばら’（C. Jabara Tanaka）も， 花粉症の症状を緩和する効果のあるナリルチン含量が高い ことから, 生産地の振興に大きく貢献している（木村ら, 2003; 中地, 2003).

三重県では, 1997 年に品種登録された香酸カンキッ“新 姫”や三重県鳥羽市で「市の木」に指定されているタチバ 
ナ（C. tachibana Tanaka）が嗜好性に優れ生食用や果汁飲料 用として栽培面積も年々増加しており，地域特産カンキッ として期待が高まっている。 これまで，タチバナ果実のフ ラボノイド含量については, 野方 (2005) が 45 種類のカン キツを比較調査し, タチバナはエリオシトリン, ナリルチ ン, ヘスペリジン, ネオポンシリン, ディオスミン, ネオ ディオスミン，シネセチン，ノビレチンおよびタンゲレチ ンを豊富に含むことを報告している，従って，タチバナの 類縁と考えられている ‘新姫” (財団法人 農産業振興奨励 会，1992）についても，タチバナと同様に機能性成分であ るフラボノイドを多く含有することが期待される. Miyake （2006）は，“新姫”果実の果皮と果汁中のフラボノイド成 分を分析した結果，果皮にエリオシトリン，ナリルチン， ヘスペリジン，ナリンギン，ノビレチンおよびタンゲレチ ンを多く含有すると報告している. 果汁商品としての利用 が考兄らる ‘新姫” には果皮の有効利用も必要となるた め, 果皮の部位別フラボノイド含量や，搾汁後の残椬とな る果肉部分の部位別含量など, 詳細な検討が求められてい る. そこで本研究では, 三重県で特産化されてきている香 酸カンキッ ‘新姫” の機能性成分であるフラボノイド含量 をフラベド，アルベド，維管束，じょらのう膜，砂じょう および種子別に明らかにし，類似カンキッ類であるシィク ワーサー, タチバナと比較検討した。

\section{材料および方法}

\section{1. 供試材料}

三重県科学技術振興センター農業研究部（紀南果樹研究 室）の実験圃場内で栽培されている ‘新姫”，シィクワー サーおよび当地域の “花の窟神社” (三重県熊野市) に自生 するタチバナの成熟果実を供試した。“新姫”拈よびタチバ ナは 2005 年 1 月 5 日, シィクワーサーは 2005 年 1 月 11 日 に採取した. ‘新姫”とシィクワーサーは 3 樹から 1 樹当た り 5 果を採取し, タチバナは 2 樹から 15 果を採取し, それ ぞれ 5 果を一群として 3 反復で分析に供試した.

採取した果実サンプルは水洗後, 果皮部と果肉部に分離 し, さらにフラベド, アルベド, 維管束, じょうのう膜, 砂じょらおよび種子に分離し, 直ちにナイロンバックに密 封して分析に供試するまで $-70^{\circ} \mathrm{C}$ で凍結保存した.

\section{2. サンプル調製}

分析用サンプルは, 分析直前に凍結乾燥（東京理化, EYELAFD-1000）した後，コーヒーミル（IWATANI-1000）で 粉砕して供試した. 粉砕サンプルからの抽出は, Kawaii ら （1999）の方法に従って行った. まず, 粉砕サンプル $100 \mathrm{mg}$ を蓋付き試験管に秤量し, 抽出溶媒 $1 \mathrm{~mL}$ [メタノール：ジ メチルスルホキシド（1:1, v/v) ] を加え, 超音波（Yamato, BRANSON 3200）処理しながら室温で 10 分間抽出した. そ の後, 遠心分離（12,000 rpm, $15 \mathrm{~min} ）$ して上清を回収した. 沈殿に抽出溶媒 $1 \mathrm{~mL}$ を加え, 上清を回収する操作を 3 回繰 り返し, $5 \mathrm{~mL}$ 容メスフラスコに定容した後, メンブランフィ
ルター（孔径 $0.2 \mu \mathrm{m} ）$ で濾過して分析に供した.

\section{3. 供試試薬および HPLC 分析条件}

エリオシトリン (ECR)，ナリルチン (NRT), ヘスペリ ジン (HSP), ネオポンシリン (NPNC) 抽よ゙シネセチン （SNT）の標品として市販されている純品（フナコシ）を用 い,ノビレチン（NBL）とタンゲレチン（TNG）の標品は, (独) 農業・食品産業技術総合研究機構果樹研究所カンキッ 研究興津拠点から提供されたものを供試した.

各フラボノイド成分は，高速液体クロマトグラフ法に 従って分離同定し，フラバノンは $285 \mathrm{~nm}$, ポリメトキシフ ラボンは $360 \mathrm{~nm}$ の吸収スペクトルを記録して定量した (Vandercook・Tisserat, 1989). すなわち，TSK-GEL SUPER ODS カラム（ $(\phi 4.6 \mathrm{~mm} \times 50 \mathrm{~mm})$ を装着した高速液体クロ マトグラフ（島津製作所, LC-10 システム, フォトダイオー ドアレイ検出器）を用い, カラムオーブン温度 $40^{\circ} \mathrm{C}$, 移動 相の流速 $1 \mathrm{~mL} \cdot \mathrm{min}^{-1}$ とし, 2 ステップもしくは 3 ステップ による 2 液グラジェント法（A 液： $10 \mathrm{mM}$ リン酸， B 液 : メタノール）によって分離した．エリオシトリン，ナリル チンおよびヘスペリジンのサンプル注入量は $4 \mu \mathrm{L}$ とし, 分 離条件は（1）0-50 分：20-80\%A 液，（2）50-60 分：1000\%A 液とした. シネセチン，ノビレチン，タンゲレチンお よびネオポンシリンのサンプル注入量は $10 \mu \mathrm{L}$ と, 分離 条件は（1）0-20 分：30-70\%A 液，（2）20-30 分：60-40\% A 液，（3）30-40 分：100-0\%A 液とした. 得られたデータ は分散分析を行い，必要に応じて Tukey 法により多重検定 を行った。

\section{結 果}

‘新姫”，タチバナおよびシィクワーサーの新鮮重と乾物重 の部位別構成割合を第 1 表に示した．新鮮重は，どの種・品 種でも砂じょうの割合が最も高かった。 ‘新姫’では, 砂じょ らの次にフラベドの割合が高くアルベド, 維管束の重量割合 は低かった. 乾物重は新鮮重と比較して, ぞの種・品種でも 砂じょらの割合が低くなり，種子の割合が高くなった。

“新姫”，タチバナおよびシィクワーサーのフラボノイド 含量を第 2 表に示した. 7 種類のフラボノイド成分は, シィ クワーサーのエリオシトリンを除き, 供試したすべてのカ ンキッで検出され，各フラボノイド成分含量の種・品種間 に有意差が認められた。 すなわち, ‘新姫’ はタチバナより もエリオシトリン，ナリルチン，ヘスペリジン，ネオポン シリン，シネセチンおよび総フラボノイド含量が高く，ノ ビレチン含量に有意差は認められず, タンゲレチン含量は 低かった. また，“新姫’はシィクワーサーよりもエリオシ トリン，ナリルチン，齐ポンシリンおよびシネセチン含 量が高く，ヘスペリジン含量に有意差は認められず，ノビ レチンとタンゲレチン含量は低かった。 フラボノイド成分 別では, ヘスペリジン含量がエリオシトリン, ナリルチン, ネオポンシリン，シネセチン，ノビレチンおよびタンゲレ チンの各含量よりも高いことが，供試したすべてのカンキ 
第 1 表 3 種の香酸カンキツにおける成熟果実の部位別重量

\begin{tabular}{|c|c|c|c|c|c|c|c|c|c|c|c|c|}
\hline \multirow{3}{*}{$\begin{array}{l}\text { 調査部位 } \\
\text { フラベド }\end{array}$} & \multicolumn{6}{|c|}{ "部位別重量（生果） } & \multicolumn{6}{|c|}{ "部位別重量（乾物） } \\
\hline & \multicolumn{2}{|c|}{$\begin{array}{l}\text { 新姫 } \\
(\mathrm{g})\end{array}$} & \multicolumn{2}{|c|}{$\begin{array}{c}\text { タチバナ } \\
\quad(\mathrm{g})\end{array}$} & \multicolumn{2}{|c|}{$\begin{array}{c}\text { シィクワーサー } \\
(\mathrm{g})\end{array}$} & \multicolumn{2}{|c|}{$\begin{array}{l}\text { 新姫 } \\
(\mathrm{g})\end{array}$} & \multicolumn{2}{|c|}{$\begin{array}{c}\text { タチバナ } \\
(\mathrm{g})\end{array}$} & \multicolumn{2}{|c|}{$\begin{array}{c}\text { シィクワーサー } \\
(\mathrm{g})\end{array}$} \\
\hline & $2.9 \mathrm{~b}^{\mathrm{z}}$ & $(14.2)^{x}$ & $1.9 b^{z}$ & $(12.1)$ & $1.8 \mathrm{~b}^{\mathrm{z}}$ & $(15.0)$ & $0.7 \mathrm{bc}^{\mathrm{y}}$ & $(17.8)$ & $0.5 \mathrm{~d}^{\mathrm{y}}$ & $(12.3)$ & $0.6 b^{y}$ & $(17.3)$ \\
\hline アルベド & $0.6 \mathrm{~d}$ & (2.9) & $0.3 \mathrm{c}$ & (1.9) & $0.2 \mathrm{~b}$ & $(2.0)$ & $0.2 \mathrm{de}$ & $(4.8)$ & $0.1 \mathrm{e}$ & $(2.2)$ & $0.1 \mathrm{c}$ & (2.6) \\
\hline 維管束 & $0.4 \mathrm{~d}$ & $(2.1)$ & $0.3 \mathrm{c}$ & $(1.7)$ & $0.4 \mathrm{~b}$ & $(3.2)$ & $0.1 \mathrm{e}$ & (3.6) & $0.1 \mathrm{e}$ & $(2.3)$ & $0.1 \mathrm{c}$ & $(4.3)$ \\
\hline じょうのう膜 & $1.9 \mathrm{c}$ & $(9.4)$ & $2.6 \mathrm{~b}$ & $(16.4)$ & $1.4 \mathrm{~b}$ & $(10.9)$ & $0.5 \mathrm{~cd}$ & $(13.5)$ & $0.8 \mathrm{~cd}$ & $(19.3)$ & $0.5 \mathrm{c}$ & $(13.2)$ \\
\hline 砂じょう & $12.6 \mathrm{a}$ & $(62.7)$ & $7.9 \mathrm{a}$ & $(50.1)$ & $7.2 \mathrm{a}$ & $(57.4)$ & $1.4 \mathrm{a}$ & $(36.3)$ & $1.0 \mathrm{~b}$ & $(24.0)$ & $1.2 \mathrm{a}$ & $(34.4)$ \\
\hline 種子 & $1.8 \mathrm{c}$ & $(8.7)$ & $2.8 \mathrm{~b}$ & $(17.8)$ & $1.4 \mathrm{~b}$ & $(11.5)$ & $0.9 \mathrm{~b}$ & $(24.0)$ & $1.7 \mathrm{a}$ & $(39.9)$ & $1.0 \mathrm{ab}$ & $(28.2)$ \\
\hline 全体重量 & 20.2 & $(100)$ & 15.7 & $(100)$ & 12.5 & $(100)$ & 3.9 & $(100)$ & 4.2 & $(100)$ & 3.5 & $(100)$ \\
\hline
\end{tabular}

${ }^{\mathrm{z}, \mathrm{y}}$ 同一列の異なる符号間に有意差有り（Tukey, ${ }^{\mathrm{z}} 1 \%$ 水準, ${ }^{\mathrm{y}} 5 \%$ 水準)

$\mathrm{x}$ 括弧内の数值は果実重に対する構成割合（\%) を示す

第 2 表 3 種の香酸カンキツに打ける成熟期の乾燥果実に含まれるフラボノイド含量

\begin{tabular}{lcccccccc}
\hline \hline \multirow{2}{*}{ 種・品種 } & \multicolumn{7}{c}{ フラボノイド含量 ${ }^{\mathrm{z}}\left(\mu \mathrm{g} ・ 100 \mathrm{mg}^{-1}\right.$ dry weight $)$} \\
\cline { 2 - 8 } & $\mathrm{ECR}^{\mathrm{y}}$ & $\mathrm{NRT}^{\mathrm{y}}$ & $\mathrm{HSP}$ & $\mathrm{NPNC}^{\mathrm{y}}$ & $\mathrm{SNT}^{\mathrm{y}}$ & $\mathrm{NBL}^{\mathrm{y}}$ & $\mathrm{TNG}^{\mathrm{y}}$ & 総量 $^{\mathrm{y}}$ \\
\hline 新姫 & $124.7 \mathrm{a}^{\mathrm{w}}$ & $99.3 \mathrm{a}^{\mathrm{w}}$ & $1273.8 \mathrm{a}^{\mathrm{w}}$ & $63.9 \mathrm{a}^{\mathrm{w}}$ & $42.3 \mathrm{a}^{\mathrm{w}}$ & $86.8 \mathrm{~b}^{\mathrm{x}}$ & $30.4 \mathrm{~b}^{\mathrm{w}}$ & $1721.2 \mathrm{a}^{\mathrm{x}}$ \\
タチバナ & $23.1 \mathrm{~b}$ & $49.9 \mathrm{~b}$ & $671.0 \mathrm{~b}$ & $34.3 \mathrm{~b}$ & $11.2 \mathrm{~b}$ & $95.7 \mathrm{ab}$ & $90.1 \mathrm{a}$ & $975.2 \mathrm{~b}$ \\
シィクワーサー & 0.0 & $17.7 \mathrm{c}$ & $1188.6 \mathrm{a}$ & $11.5 \mathrm{c}$ & $15.5 \mathrm{~b}$ & $133.1 \mathrm{a}$ & $125.5 \mathrm{a}$ & $1491.8 \mathrm{a}$ \\
\hline
\end{tabular}

$\mathrm{z}$ 果実の部位別フラボノイド濃度に部位別乾燥重量割合を乗じて算出した

${ }^{\mathrm{y}} \mathrm{ECR}$; エリオシトリン, NRT ; ナリルチン, HSP ; ヘスペリジン, NPNC ; ネオポンシリン, SNT; シネセチン, NBL ; ノビ レチン, TNG; タンゲレチン

${ }^{\mathrm{w}, \mathrm{x}}$ 同一列の異なる符号間に有意差有り（Tukey, ${ }^{\mathrm{w}} 1 \%$ 水準， ${ }^{\mathrm{x}} 5 \%$ 水準）

第 3 表 3 種の香酸カンキツにおける成熟果実の部位別フラボノイド含量

\begin{tabular}{|c|c|c|c|c|c|c|c|c|c|c|c|c|c|c|c|}
\hline \multirow{2}{*}{ 種・品種 } & \multirow{2}{*}{ 調査部位 } & \multicolumn{14}{|c|}{ フラボノイド含量 $\left(\mu \mathrm{g} ・ 100 \mathrm{mg}^{-1} \mathrm{dry}\right.$ weight $)$} \\
\hline & & \multicolumn{2}{|c|}{$\mathrm{ERC}^{\mathrm{z}}$} & \multicolumn{2}{|c|}{$\mathrm{NRT}^{\mathrm{z}}$} & \multicolumn{2}{|c|}{$\mathrm{HSP}^{\mathrm{z}}$} & \multicolumn{2}{|c|}{$\mathrm{NPNC}^{\mathrm{z}}$} & \multicolumn{2}{|c|}{$\mathrm{SNT}^{\mathrm{z}}$} & \multicolumn{2}{|c|}{$\mathrm{NBL}^{\mathrm{z}}$} & \multicolumn{2}{|c|}{$\mathrm{TNG}^{\mathrm{z}}$} \\
\hline \multirow{6}{*}{ 新姫 } & フラベド & $422 a^{y}$ & $(61.3)^{w}$ & w $5 d^{x}$ & $(0.9)$ & $1895 c^{x}$ & $(26.8)$ & $29 c^{y}$ & $(8.3)$ & $223 a^{x}$ & $(93.7)$ & $455 a^{x}$ & $(93.4)$ & $157 a^{x}$ & $(92.5)$ \\
\hline & アルベド & $383 \mathrm{a}$ & $(15.0)$ & $223 \mathrm{c}$ & $(10.5)$ & $6562 \mathrm{a}$ & $(24.6)$ & $293 \mathrm{~b}$ & $(20.6)$ & $55 \mathrm{~b}$ & $(6.3)$ & $108 \mathrm{~b}$ & $(6.1)$ & $42 \mathrm{~b}$ & $(6.8)$ \\
\hline & 維管束 & $57 \mathrm{c}$ & $(1.6)$ & 919 a & $(33.2)$ & $5709 \mathrm{~b}$ & $(16.1)$ & $577 \mathrm{a}$ & (32.4) & 0 & (0) & 0 & (0) & $2 \mathrm{c}$ & $(0.3)$ \\
\hline & じょうのう膜 & $160 \mathrm{~b}$ & (17.5) & $406 \mathrm{~b}$ & (55.4) & $2042 \mathrm{c}$ & $(21.8)$ & $183 \mathrm{~b}$ & $(38.7)$ & 0 & (0) & $3 \mathrm{c}$ & $(0.5)$ & $1 \mathrm{c}$ & $(0.4)$ \\
\hline & 砂じょら & $16 \mathrm{c}$ & $(4.6)$ & 0 & (0) & $375 \mathrm{~d}$ & $(10.7)$ & 0 & (0) & 0 & (0) & 0 & (0) & 0 & (0) \\
\hline & 種子 & 0 & (0) & 0 & (0) & 0 & (0) & 0 & (0) & 0 & (0) & 0 & (0) & 0 & (0) \\
\hline \multirow{6}{*}{ タチバナ } & フラベド & $180 a^{x}$ & $(95.8)$ & 0 & (0) & $998 \mathrm{c}^{\mathrm{y}}$ & $(18.2)$ & $20 c^{x}$ & (7.2) & $88 a^{x}$ & $(96.5)$ & $748 a^{y}$ & $(96.0)$ & $700 \mathrm{a}^{\mathrm{y}}$ & $(95.3)$ \\
\hline & アルベド & $45 \mathrm{~b}$ & $(4.2)$ & $85 c^{y}$ & (3.7) & $4158 \mathrm{~b}$ & (13.5) & $73 \mathrm{bc}$ & (4.6) & $18 \mathrm{~b}$ & $(3.5)$ & $165 \mathrm{~b}$ & (3.8) & $184 \mathrm{~b}$ & (4.5) \\
\hline & 維管束 & 0 & $(0)$ & $456 \mathrm{a}$ & $(21.6)$ & $5418 \mathrm{a}$ & $(19.0)$ & $365 \mathrm{a}$ & $(25.2)$ & 0 & $(0)$ & $8 \mathrm{c}$ & $(0.2)$ & $8 \mathrm{c}$ & $(0.2)$ \\
\hline & じょうのう膜 & 0 & (0) & $193 \mathrm{~b}$ & $(74.7)$ & $1249 \mathrm{c}$ & $(35.9)$ & $112 \mathrm{~b}$ & $(63.0)$ & 0 & (0) & 0 & (0) & 0 & (0) \\
\hline & 砂じょら & 0 & (0) & 0 & (0) & $386 \mathrm{~d}$ & (13.4) & 0 & $(0)$ & 0 & (0) & 0 & (0) & 0 & (0) \\
\hline & 種子 & 0 & (0) & 0 & (0) & 0 & (0) & 0 & (0) & 0 & (0) & 0 & (0) & 0 & (0) \\
\hline \multirow{6}{*}{ シィクワーサー } & フラベド & 0 & (0) & 0 & (0) & $1772 c^{x}$ & $(25.7)$ & 0 & (0) & $29 a^{x}$ & (97.1) & $387 a^{x}$ & $(96.8)$ & $242 a^{x}$ & $(96.2)$ \\
\hline & アルベド & 0 & (0) & $18 \mathrm{c}^{\mathrm{x}}$ & $(2.7)$ & $5153 \mathrm{~b}$ & (11.5) & 0 & (0) & $18 \mathrm{~b}$ & $(2.9)$ & $240 \mathrm{~b}$ & $(3.2)$ & $162 \mathrm{~b}$ & (3.8) \\
\hline & 維管束 & 0 & (0) & $200 \mathrm{a}$ & $(48.5)$ & $7828 \mathrm{a}$ & $(28.2)$ & $116 \mathrm{a}^{\mathrm{x}}$ & (41.9) & 0 & $(0)$ & 0 & $(0)$ & 0 & (0) \\
\hline & じょらのう膜 & 0 & (0) & $65 \mathrm{~b}$ & $(48.8)$ & $2107 \mathrm{c}$ & $(23.3)$ & $52 \mathrm{~b}$ & $(58.1)$ & 0 & (0) & 0 & (0) & 0 & (0) \\
\hline & 砂じょら & 0 & (0) & 0 & (0) & $391 \mathrm{~d}$ & (11.3) & 0 & (0) & 0 & (0) & 0 & (0) & 0 & (0) \\
\hline & 種子 & 0 & (0) & 0 & (0) & 0 & $(0)$ & 0 & (0) & 0 & $(0)$ & 0 & $(0)$ & 0 & (0) \\
\hline
\end{tabular}

${ }^{\mathrm{z}} \mathrm{ECR}$; エリオシトリン, NRT ; ナリルチン, HSP ; ヘスペリジン, NPNC；ネオポンシリン, SNT；シネセチン, NBL；ノビレチン, TNG；タンゲレチン

${ }^{\mathrm{x}, \mathrm{y}}$ 同一列の異なる符号間に同一品種の部位間で有意差有り（Tukey, ${ }^{\mathrm{x}} 1 \%$ 水準, ${ }^{\mathrm{y}} 5 \%$ 水準）

${ }^{\mathrm{w}}$ 括弧内の数值は各フラボノイド成分の部位別割合（\%)

ツにおいて認められた。

‘新姫’，タチバナ拈よびシィクワーサーの部位別フラボ ノイド含量を第 3 表に示した. 各フラボノイド成分含量に は，部位間で有意差が認められた。 ‘新姫’では，エリオシ トリン含量はフラベドとアルベドで最も高く，次いでじょ
らのら膜で高く，維管束と砂じょらにも認められた. タチ バナではフラベドで高く, アルベドでも検出された.なお, フラベドでの含量は ‘新姫”の拈よそ43\%であった。一方, シィクワーサーでは全く検出されなかった。 ‘新姫’のナリ ルチン含量は維管束, じょうのう膜, アルベドの順に高く, 
フラベドでも検出された. タチバナとシィクワーサーでも 維管束, じょうのう膜, アルベドの順に高く, その他の部 位では検出されなかった。、スペリジンは，供試したすべ てのカンキッで最も多く含まれるフラボノイド成分で, 種 子以外の部位で検出された。 ‘新姫” はアルベド, 維管束, じょらのう膜の順に含有量が高く, 砂じょらでも検出され た。また，タチバナとシィクワーサーでも維管束，アルベ ド, じょらのう膜, 砂じょらの順に含有量が高かった。 ネ オポンシリンは, ‘新姫’では維管束, アルベド, じょらの ら膜, フラベドの順に高かった。 な扔，シィクワーサーで は，フラベドおよびアルベドで検出されなかった，シネセ チン，ノビレチン拈よびタンゲレチンは，供試したすべて のカンキッのフラベドとアルベドで検出され，いずれもフ ラベドに多く含有されていた.

\section{考察}

野方（2005）は，成熟果実をフラベド，アルベド，じょ らのら膜, 果肉に分画して調查し, 本研究で調査対象とし たフラボノイド成分についてタチバナでは，エリオシトリ ン, ナリルチン, ヘスペリジン, シネセチン，ノビレチン， タンゲレチンがフラベドに多く，アルベドでも検出される こと，へスペリジンとシネセチンはアルベドで最も高かっ たことを報告している。 また，シィクワーサーでも，各 ラボノイドの部位別分布パターンは，タチバナと同様の傾 向であることを報告している. 本研究では ‘新姫”, タチバ ナ拉よびシィクワーサーとも, 各フラボノイド成分が分布 する主要な組織・器官は泳济同様の傾向を示し, エリオシ トリン, シネセチン, ノビレチン, タンゲレチン含量は> ラベドで最も高く，ナリルチンとネオポンシリン含量は維 管束で最も高く，へスペリジンは維管束とアルベドで最も 高かった．これは，野方（2005）が維管束とアルベドを同 一分画として分析したことを考慮すれば，ほぼ一致する。 また，Miyake（2006）は，“新姫”の抗酸化活性はシィク ワーサーより有意に高く，その理由としてエリオシトリン 含有量が高いことと関係していると報告している. 本研究 に招いても，“新姫”にはエリオシトリンが多く含まれるこ とが認められた。

一方，野方（2005）に上机ば，タチバナ生果実 $100 \mathrm{~g}$ 当 たりのエリオシトリン，ナリルチン，へスペリジン，ネオ ポンシリン, シネセチン, ノビレチン, タンゲレチン含量 はそれぞれ 9.1，6.1，328，2.6，6.5，54.3，42 mg，シィク ワーサーではそれぞれ 2，6，411，3.2，1.8，30.3，18 mg であった。例えば，へスペリジンを例とした場合，本研究 で得られたタチバナとシィクワーサー果実の乾物部位別》 ラボノイド濃度から部位別の新鮮部分に含まれるフラボノ イド含量を算出し，さらに部位別新鮮重量割合を乗じて算 出した生果実 $100 \mathrm{~g}$ 当たりのへスペリジン含量は, それぞ れ $166.8 \mathrm{mg}$ と $274.8 \mathrm{mg}$ であり, 野方(2005)の分析值 $328 \mathrm{mg}$ と $411 \mathrm{mg}$ よりも顕著に低かった。 また, 本研究に供した夕
チバナのエリオシトリン，シネセチン，ノビレチン，タン ゲレチン含量は, 野方 (2005) の分析值のそれぞれ 63\%, 43\%，44\%，53\%であった. 一方，シィクワーサーのナリ ルチン, シネセチン, タンゲレチンは, 野方 (2005) の分 析值のそれぞれ 76\%，200\%，160\%であり，ノビレチンは ほぼ同じ含量であった，含有成分が様々な要因によって変 動することは，一般に見られる現象である。例えば，シィク ワーサーについては多くの系統が報告されて和り，果皮に 含まれるフラボノイド含量にも差が見られる (寺本 (稲福) ら，2010）。このように, 本研究結果と野方 (2005) のフラ ボノイド成分含量の違いについても，系統間差異（Kawaii ら，1999）, 成熟に伴ら変化 (土田ら，1996）, 産地間差異, 地形・日当たり条件などに起因する個体間差なぞが影響し た結果と推察された。また，Miyake（2006）は，“新姫”の フラボノイド成分の抽出条件を吟味した結果，5分間抽出 では 60 分間抽出の収率の $50 \%$ に止まると報告している.す なわち, 野方 (2005) の分析と本研究での分析に抢ける抽 出溶媒は，いずれもメタノール：ジメチルスルホキシド (1:1，v/v) で同一であったが，抽出時間は，本研究で採 用した室温 10 分 $\times 3$ 回に対して, 野方 (2005) は室温 12 時間であった。このような抽出時間の違いもフラボノイド 成分の分析值に影響したと考兄られる。

これらフラボノイドに焦点を当てた機能性食品の開発に 扔いては，料理用生食の他，果汁製造法孔重要な課題と思 われる。 ‘新姫’ は，本来じょらのう膜や果肉を摄取する生 食用よりも，果汁製造用としての用途の可能性が高い。 ルベドやフラベドに多く含まれるノビレチンやタンゲレチ ンは，果実に十分圧力をかけないと抽出できない。“新姫” のフラボノイド成分の抽出には熱水抽出が有効であるとの 報告もあり (Miyake, 2006)，こ机ら加圧方法や抽出方法の 違いとフラボノイド成分の果汁への移行率については, 今 後検討される必要がある。

以上のように，“新姫”はタチバナやシィクワーサーより もエリオシトリン，ナリルチン，ネオポンシリン，シネセ チンを多く含有し，これらフラボノイド成分はフラベド， じょらのう膜, 維管束に多く分布することが認められた.

\section{摘 要}

香酸カンキッ“新姫”，タチバナ（C. tachibana Tanaka）, シィクワーサー（C. depressa Hayata）成熟果実のフラボ） イド含量をフラベド，アルベド，維管束，じょうのう膜， 砂じょら打よび種子に分別して比較検討した。 フラボノイ ドは高速液体クロマトグラフ法に従って分離同定し，エリ オシトリン, ナリルチン, ヘスペリジン，ネオポンシリン， シネセチン，ノビレチン，タンゲレチンを分析定量した. その結果, 7 種類のフラボノイド成分の含量は, 種・品種 間拈よび部位間で有意差が認められた。“新姫’は，シィク ワーサーとタチバナよりもエリオシトリン，ナリルチン， ネオポンシリン，シネセチンの各含量が高かった．また， 7 
種類のフラボノイド含量の総和は, タチバナより高かった. 一方, ノビレチン含量はシィクワーサーの $65 \%$ と有意に低 く, タチバナと同程度であった。.タンゲレチン含量は, タ チバナとシィクワーサーのそれぞれ 30\%, 24\%と有意に低 かった。 ‘新姫”果実の部位別のフラボノイド含有量は, エ リオシトリン，シネセチン，ノビレチンおよびタンゲレチ ンがフラベドで最も高く，ナリルチンとネオポンシリンが 維管束で最も高く, ヘスペリジンが維管束とアルベドで最 も高かった。

謝 辞 本研究の遂行に当たり, 特に統計処理法をご指 導賜りました三重県農業大学校坂本 登教授に深く感謝申 し上げます。また，本研究は“アグリビジネス化支援研究 開発事業（2004～2006 年）として実施したことを記して， 感謝いたします。

\section{引用文献}

荒井綜一. 1999. 食品の機能の研究と実践 現状および未 来像. 農及園. 74: 221-225.

Bracke, M. E., E. A. Bruyneel, S. J. Vermeulen, K. Vennekens, V. V. Marck and M. M. Mareel. 1994. Citrus flavonoid effect on tumor invasion and metastasis. Food Technol. 48: 121-124.

Ishiwa, J., T. Sato, Y. Mimaki, Y. Sashida, M. Yano and A. Ito. 2000. A citrus flavonoid, nobiletin, suppresses production and gene expression of matrix metalloproteinase 9/gelatinase $\mathrm{B}$ in rabbit synovial fibroblasts. J. Rheumatol 27: 20-25.

Kanno, S., A. Shouji, K. Asou and M. Ishikawa. 2003. Effects of naringin on hydrogen peroxide-induced cytotoxicity and apoptosis in P388 cells. J. Pharmacol. Sci. 92: 166-170.

Kawaii, S., Y. Tomono, E. Katase, K. Ogawa and M. Yano. 1999. Quantitation of flavonoid constituents in citrus fruits. J. Agric. Food Chem. 47: 3565-3571.

Kim, H. K., T. S. Jeong, M. K. Lee, Y. B. Park and M. S. Choi. 2003. Lipid-lowering efficacy of hesperetin metabolites in high-cholesterol fed rats. Clin. Chim. Acta 327: 129-137.

木村美和子 - 山西妃早子 - 尾崎嘉彦 - 実宝智子. 2003. 力 ンキッ果実の脱顆粒抑制作用の探索. 和歌山県工業技 術センタ一研究報告. 2003: 1-2.

久保道徳 - 矢野眞紀 - 松田秀秋. 1989. 柑橘類果実の薬理 学的研究. (第1 報) ウンシュウミカン果実の抗アレル ギ一作用 その1. 薬学雑誌. 109: 835-842.

Manthey, J. A. 2000. Biological properties of flavonoids pertaining to inflammation. Microcirculation 7: S29-S34.

間艼谷 徹・田中敬一. 2003. くだもののはたらき. p. 4092. 日本園芸農業共同組合連合会. 東京.

松田秀秋 - 矢野眞紀 - 久保道徳 - 飯沼宗和 - 大山雅義 - 水 野瑞夫. 1991. 柑橘類果実の薬理学的研究 (第2報) ウ ンシュウミカン果実の抗アレルギー作用 その 2 フ ラボノイド成分について. 薬学雑誌. 111: 193-198.

Minagawa, A., Y. Otani, T. Kubota, N. Wada, T. Furukawa, K. Kumai, K. Kameyama, Y. Okada, M. Fujii, M. Yano, T.
Sato, A. Ito and M. Kitajima. 2001. The citrus flavonoid, nobiletin, inhibits peritoneal dissemination of human gastric carcinoma in SCID mice. Jpn J Cancer Res. 92: 1322-1328.

Miyake, Y. 2006. Characteristics of flavonoids in Niihime fruit-a new sour citrus fruit. Food Sci. Technol. Res. 12: 186-193.

Murakami, A., Y. Nakamura, K. Torikai, T. Tanaka, T. Koshiba, K. Koshimizu, S. Kuwahara, Y. Takahashi, K. Ogawa, M. Yano, H. Tokuda, H. Nishino, Y. Mimaki, Y. Sashida, S. Kitanaka and H. Ohigashi. 2000. Inhibitory effect of citrus nobiletin on phorbol ester-induced skin inflammation, oxidative stress, and tumor promotion in mice. Cancer Res. 60: 5059-5066.

中地克之. 2003. 香酸カンキツの最新情報を探る 筏下り と共に北山村の活性化を支える柑樀「ジャバラ」. 果実 日本. 58: 22-25.

野方洋一. 2005. カンキッ果実の機能性成分の検索とその 有効利用に関する研究. 近畿中国四国農研報. 5: 19-84. 太田英明. 2004. 地域特産物の生理機能性 - 活用便覧. p. 490-495. サイエンスフォーラム。東京.

Sato, T., L. Koike, Y. Miyata, M. Hirata, Y. Mimaki, Y. Sashida, M. Yano and A. Ito. 2002. Inhibition of activator polymethoxy flavonoid, results in augmentation of tissue inhibitor of metalloproteinases-1 production and suppression of production of matrix metalloproteinases-1 and -9 in human fibrosarcoma HT-1080 cells. Cancer Res. 62: 1025-1029.

隅田孝司・東 誠広・小川浩史・田中卓二. 1999. 温州 ミ カン果汁の $\beta$-クリプトキサンチン高含有粉末によるア ゾキシメタン誘発ラットの大腸ガン前駆病変抑制. 食 科工誌. 46: 473-479.

Tanaka, T., K. Kawabata, M. Kakumoto, K. Matsunaga, H. Mori, A. Murakami, W. Kuki, Y. Takahashi, H. Yonei, K. Satoh, A. Hara, M. Maeda, T. Ota, S. Odashima, K. Koshimizu and H. Ohigashi. 1998. Chemoprevention of 4-nitroquinoline 1oxide-induced oral carcinogenesis by citrus auraptene in rats. Carcinogenesis 19: 425-431.

寺本 (稲福) さゆり・山本雅史・金城秀安・北島 宣・和 田浩二・川満芳信. 2010. 沖縄本島北部のカンキッ遺 伝資源执よびそのポリメトキシフラボン含量. 園学研. 9: 263-271.

土田貴志・山本知枝・山本恵一 - 人見信之・小坂 昇・鹿 野英士・岡野正道・小松かつ子・難波恒雄. 1996. 柑 橘類生薬の基源と品質に関する研究（第 1 報）Citrus 属 5 種の果皮の成分及び組織形態の成熟に伴ら変化. 生 薬学雑誌. 50: 114-127.

Vandercook, C. E. and B. Tisserat. 1989. Flavonoid changes in developing lemons grown in vivo and in vitro. Phytochemistry 28: 799-803.

矢野昌充. 1999. 果実類の生理機能. 農及園. 74: 113-118. 財団法人 農産業振興奨励会. 1992. 平成 $2 \cdot 3$ 年度新果樹 探索調査委託事業報告書. 189-200。 